\title{
COMPARISON OF PHYSIOLOGICAL EFFECTS OF OSMOTIC STRESS ON TWO WHEAT GENOTYPES
}

\author{
Elisaveta Kirova, Irina Moskova*, Tania Kartseva, Konstantina Kocheva \\ Bulgarian Academy of Sciences, Institute of Plant Physiology and Genetics, Acad. G. Bonchev Str. 21, \\ 1113 Sofia, Bulgaria \\ "Corresponding author. E-mail: irina_mos@abv.bg
}

\begin{abstract}
Kirova E., Moskova I., Kartseva T., Kocheva K., 2021: Comparison of physiological effects of osmotic stress on two wheat genotypes. - Botanica, 27(2): 134-140.

Revealing stress tolerance mechanisms in plants would contribute to the selection of crop varieties with a higher capacity for surviving in unfavourable environments. In this regard, it is essential to identify possible physiological features that might be beneficial for increasing plant resistance to stress. Two contrasting common wheat (Triticum aestivum L.) cultivars with different drought tolerance were subjected to $48 \mathrm{~h}$ treatment with $20 \%$ polyethylene glycol 8000 , which provoked an extra degree of osmotic and oxidative stress as well as distinct physiological responses. Better water retention capacity in leaves and lesser extent of membrane injury found in cultivar 'Guinness' compared to cultivar 'Niki' correlated with increased osmotic adjustment by accumulating higher amounts of proline and higher antioxidant scavenging capacity in the former. Compared to soluble sugars and total free amino acids, proline contributed to a greater extent to preserving leaf water. It was speculated that such a combination of features would set a genotypic advantage for this cultivar, which could also determine better performance under drought conditions in the field.
\end{abstract}

Keywords: antioxidant capacity, membrane injury, proline, reactive oxygen species, Triticum aestivum.

\section{INTRODUCTION}

Unfavourable environmental conditions negatively affect the productivity of crop plants. Drought is one of the most common limiting factors for harvest yield and has an incredibly damaging effect at the early stages of plant growth (Mattos \& MoretTi, 2015). However, abiotic factors always appear in combination in the field, making it more challenging to assess the impact of different factors such as drought, salinity or suboptimal temperatures (HE et al., 2018). Moreover, each factor eventually induces osmotic stress in the plant organism (SLAmA et al., 2015). In this regard, many scientists perform laboratory experiments, imposing osmotic stress by treating plants with solutions of polyethylene glycol (PEG), which simulates the effect of dehydration in the field
(MA et al., 2014). The use of PEG offers the possibility of inducing various degrees of stress, receiving reproducible results, and separating the effect of water deficit or dehydration from that of other abiotic factors. The study of physiological processes in plants reveals the plasticity of biochemical pathways and the limits of their functioning. It increases our knowledge of the mechanisms for survival in hostile conditions (BASU et al., 2016).

Under drought conditions, plants need to sustain water relations by synthesising and accumulating compatible solutes such as free amino acids, sugars, and proline. This is the essence of the essential physiological process of osmotic adjustment, which allows the plant to maintain turgor at low water potentials and preserve metabolic functions (BASU et al., 2016; ABID et al., 2018). 
Wheat is a common crop worldwide, and maintaining its productivity under adverse environments is an essential goal for breeders. The induction of oxidative stress is among the adverse effects of drought at the cellular level. Like many other environmental stresses, drought also causes oxidative damage due to the accumulation of reactive oxygen species (ROS) such as hydrogen peroxide, singlet oxygen and hydroxyl radicals (Gill \& TutejA, 2010). Generation and overproduction of ROS could impair most cellular components: proteins, lipids, carbohydrates and DNA (Gill \& TuteJA, 2010). However, an efficient antioxidant system protects plants from oxidative damage and thus contributes to improving stress tolerance. In the present work, we investigate the effect of osmotic stress on young common wheat plants from two cultivars to assess different genotypes' performance and stress management strategies.

The present work aimed to evaluate the physiological performance of young wheat plants subjected to osmotic stress and find out whether it correlated with their drought tolerance in the field. The main task was to assess the efficiency of the antioxidant defence system and its contribution to the stress tolerance of wheat cultivars with different drought susceptibility. Dehydration induced changes in the quantity of distinctive biochemical stress markers were also estimated.

\section{MATERIALS AND METHODS}

\section{Plant material and growing conditions}

Two common wheat (Triticum aestivum L.) cultivars were used in the experiments, which differ in their drought tolerance in the field: cultivar 'Guinness' has very high drought tolerance. In contrast, cultivar 'Niki' is less tolerant (ChipILsKi, 2015). After germination on wet filter paper for two days at $21^{\circ} \mathrm{C}$, young seedlings were transferred to a half-strength Hoagland nutrient solution in a climatic chamber with a $12 \mathrm{~h}$ photoperiod, $60 \%$ relative humidity and $25 / 20^{\circ} \mathrm{C}$ day/ night temperatures. Osmotic stress was imposed on 10 -day-old seedlings by soaking their roots in $20 \%$ PEG 8000 (Fluka, Germany) for 48 h. Plants remaining on nutrient solution served as untreated controls.

Relative water content (RWC) in the leaves was estimated as described in TURNER (1981) and was calculated from the equation:

$$
\mathrm{RWC}=(\mathrm{FW}-\mathrm{DW}) /(\mathrm{TW}-\mathrm{DW}) \times 100,
$$

where FW is the fresh weight of the leaves, TW is the weight at full turgor, measured after floating the leaves for $24 \mathrm{~h}$ on the water in the light at room temperature, and DW is the weight estimated after drying the leaves for at least $4 \mathrm{~h}$ at $80^{\circ} \mathrm{C}$ or until a constant weight is achieved.

Membrane injury index was estimated by measuring electrolyte leakage from leaves and calculated from the equation:

$$
\mathrm{I}=\left[1-\left(1-\mathrm{T}_{1} / \mathrm{T}_{2}\right) /\left(1-\mathrm{C}_{1} / \mathrm{C}_{2}\right)\right] \times 100,
$$

where $T_{1}$ and $T_{2}$ are conductivity values of treated samples before and after destroying the tissues by boiling, and $\mathrm{C}_{1}$ and $\mathrm{C}_{2}$ are values of respective controls (ElBasyoni et al., 2017).

Biochemical analyses were carried out using fresh material from the first fully developed plants' leaves in six technical replications.

Free proline content was evaluated in fresh leaf tissue by the ninhydrin method (BATEs et al., 1973). Fresh leaf material (300 mg) was ground in 3\% sulfosalicylic acid and subsequently finely filtered. The filtrate reacted with glacial acetic acid and freshly prepared acid-ninhydrin reagent for $60 \mathrm{~min}$ at $100^{\circ} \mathrm{C}$. Absorption was recorded at $520 \mathrm{~nm}$, and proline concentration was calculated from a previously prepared standard curve with known concentrations of L-proline (Fluka, Germany). To estimate total amino acids and reducing sugars, ethanol extracts were prepared by stirring $1 \mathrm{~g}$ of fresh leaf tissue in $5 \mathrm{ml} \mathrm{95 \%} \mathrm{ethanol} \mathrm{followed} \mathrm{by} \mathrm{a}$ subsequent triple rinse with $5 \mathrm{ml}$ of $70 \%$ ethanol. After centrifugation at $4500 \mathrm{~g}$ for $5 \mathrm{~min}$, supernatants were collected, evaporated to dryness and dissolved in $1 \mathrm{ml}$ deionised water and used for further analysis.

Total amino acid content was determined according to the ninhydrin reaction, and absorbance was recorded at $570 \mathrm{~nm}$ (Yemm \& Cocking, 1955). In addition, a previously plotted standard curve was prepared using a mixture of equivalent concentrations of L-glutamine and L-asparagine (Fluka, Germany).

Reducing sugars were analysed by the phenolsulphuric acid procedure of hydrolysation of sucrose, and extinction was read at $490 \mathrm{~nm}$ using glucose as standard (AsHwell, 1966). 
Total phenolic content was assessed by SwAIN \& GoLDSTEIN (1964) method involving a reaction mixture of leaf extract and Folin-Ciocalteu reagent incubated in the presence of $1 \mathrm{M} \mathrm{Na}_{2} \mathrm{CO}_{3}$ for $2 \mathrm{~h}$ at room temperature. Absorbance was recorded at $725 \mathrm{~nm}$, and a standard curve was prepared with gallic acid.

Flavonoid content was determined as described in Zhishen et al. (1999). Ethanol leaf extracts (1 g fresh material was extracted with $100 \mathrm{ml} 95 \%$ ethanol for $60 \mathrm{~min}$ ) reacted with $\mathrm{NaNO}_{2}(1: 20)$ for $5 \mathrm{~min}$, then $\mathrm{AlCl}_{3}$ and $\mathrm{NaOH}$ were subsequently added and well mixed. Absorbance was measured at $510 \mathrm{~nm}$ on a spectrophotometer Shimadzu UV-1601 UV-Visible (Shimadzu, Japan), and flavonoid content was expressed in rutin equivalents.

Malondialdehyde (MDA) content was estimated after CAKMAK \& HORST (1991). Leaf material was homogenised in $0.1 \%$ trichloroacetic acid (TCA) and centrifuged for $20 \mathrm{~min}$ at $10000 \mathrm{~g}$. Aliquots of the supernatant reacted with $0.5 \%(\mathrm{w} / \mathrm{v})$ thiobarbituric acid dissolved in $20 \%$ TCA for $30 \mathrm{~min}$ at $100^{\circ} \mathrm{C}$. Absorbance was measured at $532 \mathrm{~nm}$ with correction at $600 \mathrm{~nm}$, and MDA content was calculated with a molar extinction coefficient $155^{-1} \mathrm{~cm}^{-1}$.

Hydrogen peroxide $\left(\mathrm{H}_{2} \mathrm{O}_{2}\right)$ was measured according to Alexieva et al. (2001) in a reaction mixture from $0.5 \mathrm{ml}$ leaf extract $(0.3 \mathrm{~g}$ leaf material was ground in $0.5 \%$ TCA and $100 \mathrm{mM} \mathrm{K}$-phosphate buffer at $\mathrm{pH} 7.4$ ) and $2 \mathrm{ml} 0.5 \mathrm{M} \mathrm{KI}$. It was developed for $60 \mathrm{~min}$ in darkness, after which absorbance was measured at $352 \mathrm{~nm}$, and hydrogen peroxide was calculated from a standard curve prepared with known amounts of the substance.

Ferric reducing antioxidant power (FRAP) assay was used to assess total antioxidant activity (BenZIE \& Szeto, 1999). Leaf extract was prepared by grinding $1 \mathrm{~g}$ plant material with $10 \mathrm{ml} 80 \%$ ethanol in the ice bath and then centrifuging the homogenate at $10000 \mathrm{~g}$ for $20 \mathrm{~min}$ at $4^{\circ} \mathrm{C}$. Aliquots of $100 \mu \mathrm{l}$ supernatant reacted for $10 \mathrm{~min}$ at $37^{\circ} \mathrm{C}$ with $3 \mathrm{ml}$ FRAP reagent prepared with $300 \mathrm{mM}$ acetate buffer (pH 3.6), 10mM TPTZ (2,4,6-tripyridyl-s-triazine), $40 \mathrm{mM} \mathrm{HCL}$ and $20 \mathrm{mM} \mathrm{FeCl}_{3} \cdot 6 \mathrm{H}_{2} \mathrm{O}$. The reduction of the $\mathrm{Fe}^{3+} /$ tripyridultraizine complex by leaf extracts was detected by measuring the increase in absorbance at $593 \mathrm{~nm}$. Values were expressed as antioxidant concentration having a ferric reducing ability equivalent to that of $1 \mathrm{mmol} / 1 \mathrm{FeSO}_{4}$.

Free radicals scavenging activity was measured according to BRAND-Williams et al. (1995), using 1,1-diphenyl-2-picrylhydrazyl (DPPH). Methanol solution of $60 \mu \mathrm{M}$ DPPH was mixed with $100 \mu \mathrm{l}$ plant extract. The absorbance decrease was recorded at $517 \mathrm{~nm}$ using a spectrophotometer, representing the transformation of the initial oxidised to the reduced form of DPPH. The per cent inhibition of DPPH (\%) was calculated by the equation:

$$
\text { DPPH }(\%)=\left[\left(\mathrm{A}_{\text {blank }}-\mathrm{A}_{\text {sample }}\right) / \mathrm{A}_{\text {blank }}\right] \times 100 \text {, }
$$

where $\mathrm{A}_{\text {blank }}$ is the absorbance of the control reaction (containing all reagents except the extract), and $\mathrm{A}_{\text {sam- }}$ ple is the absorbance of the extract.

\section{Statistical analysis}

Data from two independent experiments with at least three technical replications were subjected to one-way analysis of variance (ANOVA). Mean values and standard errors (SE) were calculated, and the significance of differences at $p<0.05$ was analysed using Ducan's multiple range test. Statistical analyses were performed using Statgraphics Plus, version 5.1 for Windows.

\section{RESULTS}

Osmotic stress with PEG caused a severe reduction in leaf water content in both studied wheat genotypes. Still, better-preserved leaf hydration was observed in 'Guinness', which retained higher RWC values (Fig. 1a). A higher degree of membrane injury following PEG treatment in comparison to untreated controls was found in 'Niki', while 'Guinness' was less affected (Fig. 1b). Under control conditions, 'Niki' had significantly higher hydrogen peroxide present in the leaves than 'Guinness'. After dehydration, $\mathrm{H}_{2} \mathrm{O}_{2}$ levels in both cultivars increased, with 'Niki' sustaining higher amounts of $\mathrm{H}_{2} \mathrm{O}_{2}$ in the leaves than 'Guinness' (Fig. 1c). However, control levels of MDA in the leaves of the two cultivars differed with higher values estimated in 'Guinness'. Dehydration caused a $23 \%$ increase in MDA in 'Niki', while in 


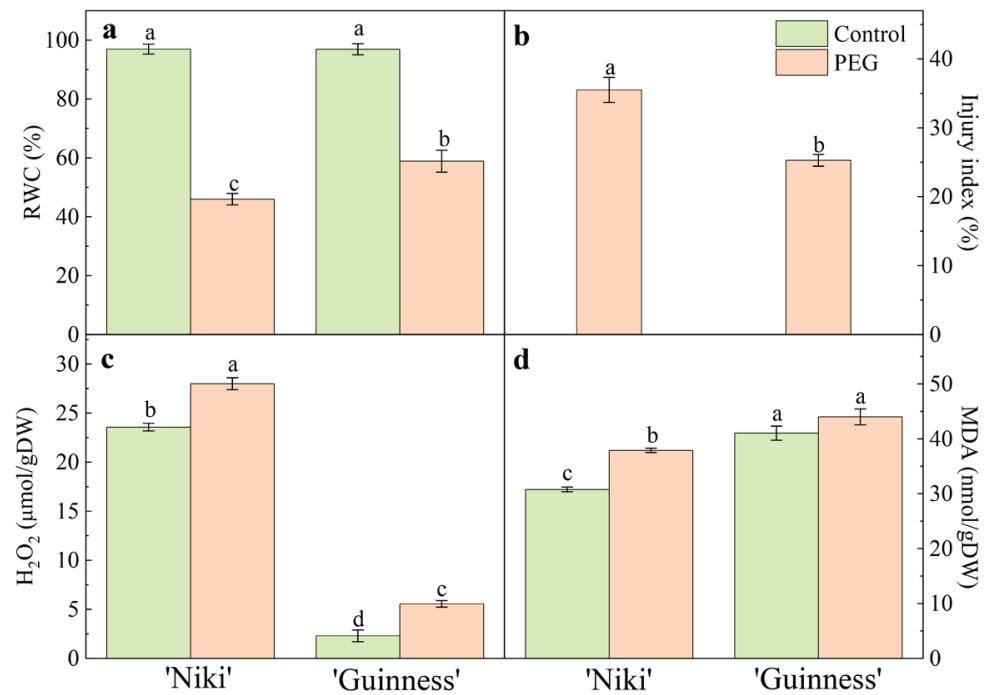

Fig. 1. Relative water content (RWC) (a), Injury index (b), $\mathrm{H}_{2} \mathrm{O}_{2}$ (c) and malondialdehyde (MDA) (d) in leaves of two wheat cultivars subjected to osmotic stress with $20 \%$ polyethylene glycol (PEG) 8000 and in controls. Data are means \pm SE $(n=6)$. Different letters represent significant differences at $p<0.05$

'Guinness' significant increase in MDA was not detected (Fig. 1d).

Both cultivars' free proline content in control plants was similar, but osmotic stress caused a more significant increase in the amounts of this imino acid in cv. 'Guinness', more than 16-fold, while 'Niki' proline increased 11.8-fold compared to respective controls (Fig. 2a). Higher amounts of amino acids were measured in 'Niki' than in 'Guinness' under control conditions, and PEG treatment induced an increment of $c a$. $62 \%$ in 'Niki' and only $43 \%$ in 'Guinness' (Fig. 2b). Increased amounts of reducing sugars were observed in the leaves of the two studied wheat genotypes in response to the induced osmotic stress. In 'Niki' leaf sugar content increased twice due to dehydration, while in 'Guinness', the increase was almost 3-fold (Fig. 2c).

Control levels of flavonoids were almost three times higher in 'Niki' compared to 'Guinness'. However, osmotic stress caused a more significant increase in these substances in 'Guinness' (Fig. 3a). Phenolic compounds were higher in 'Niki' compared to 'Guinness' under control conditions. Although osmotic stress caused a more significant increase in their content in 'Niki', still higher phenols were measured in 'Niki' (Fig. 3b). Higher antioxidant activity was observed in 'Niki' controls, but PEG treatment induced greater increases in FRAP in 'Guinness' (Fig. 3c). Higher amounts of DPPH were observed in cv. 'Guinness' under control as well as under osmotic stress conditions (Fig. 3d).

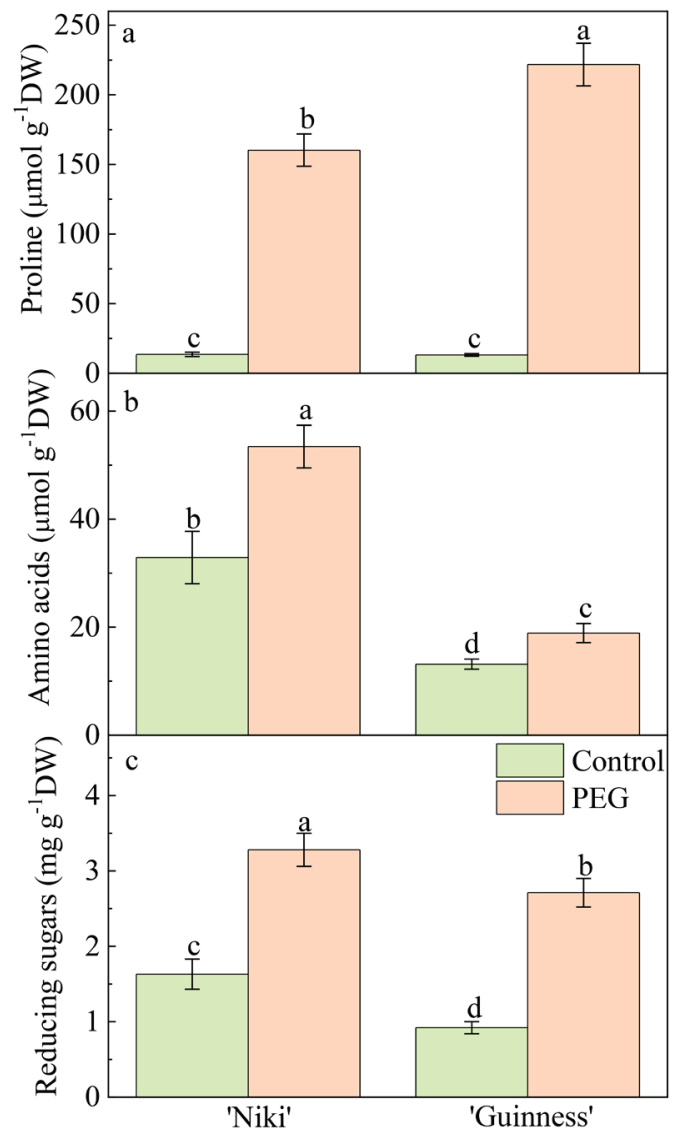

Fig. 2. Amounts of free proline (a), total amino acids (b), and reducing sugars (c) in leaves of two wheat cultivars subjected to osmotic stress with $20 \%$ polyethylene glycol (PEG) 8000 and in controls. Data are means $\pm \operatorname{SE}(n=6)$. Different letters represent significant differences at $p<0.05$ 


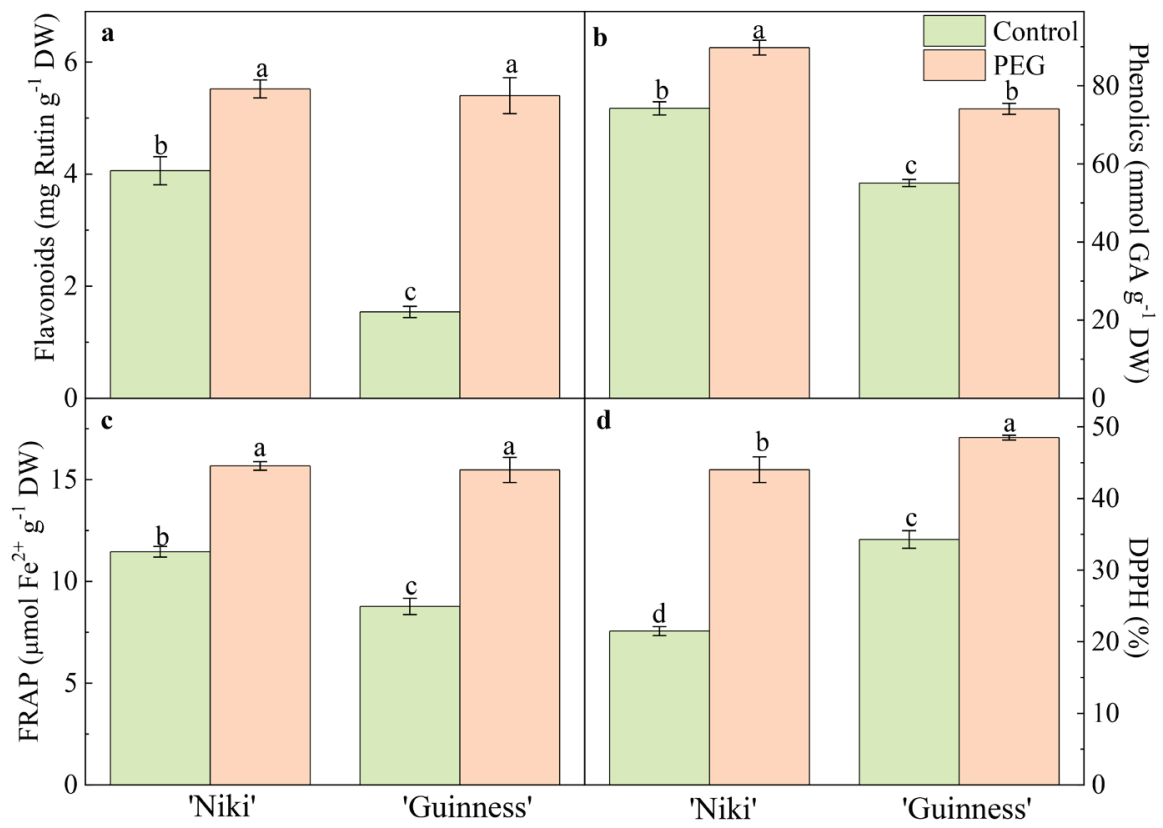

Fig. 3. Leaf content of flavonoids (a), total phenolics (b), ferric reducing antioxidant power (FRAP) (c), and 1,1-diphenyl-2picrylhydrazyl (DPPH) (d) in leaves of two wheat cultivars subjected to osmotic stress with $20 \%$ polyethylene glycol 8000 and in controls. Data are means $\pm \mathrm{SE}(\mathrm{n}=6)$. Different letters represent significant differences at $p<0.05$

\section{DISCUSSION}

Plant responses to drought stress involve metabolic changes which support survival in an adverse environment. The first symptom of dehydration is loss of turgor due to water disappearance from tissues. Maintenance of cellular and tissue water content and preservation of membrane integrity are of primary importance for sustaining plant metabolism (АвовАттА, 2019). Under the provoked dehydration through PEG treatment, both wheat genotypes experienced leaf water loss evidenced by decreased RWC. Dehydration was accompanied by impaired membrane permeability, more clearly observed in 'Niki' along with higher amounts of hydrogen peroxide estimated after PEG treatment. The damaging effect of hydrogen peroxide on cellular membranes could be attributed to its action as ROS. MDA formation is another reliable indicator of membrane damage resulting from the peroxidation of membrane lipids (Ma et al., 2014; Sperdouli \& Moustakas, 2012). MDA increased in 'Niki' under osmotic stress, while 'Guinness' did not have significantly higher amounts compared to respective controls. It could be concluded that plants from 'Niki' experienced more significant oxidative damage than those from 'Guinness'.

Various protective mechanisms exist in plants for coping with the adverse effects of stress, which involve osmoregulation and scavenging of toxic ROS by enzymes or powerful antioxidants (MA et al., 2014; BLum, 2017). Osmoregulation could be achieved by accumulating low molecular substances called compatible solutes like amino acids, sugars, polyols, and polyamines that contribute to osmotic adjustment by counteracting the effects of dehydration at the cellular level (Slama et al., 2015; Blum, 2017). Besides osmoprotection, other functions attributed to these substances are sources of energy and reducing power, protecting proteins from denaturation and ROS scavenging capacity. Higher amounts of proline were accumulated in 'Guinness' in response to PEG treatment, while in 'Niki', amino acids and reducing sugars were preferred compatible solutes. However, it should be concluded that 'Guinness' demonstrated better osmotic adjustment, which probably contributed to better water retention capacity and membrane protection. A possible function of proline was associated with its role in protecting membranes from oxidative stress (Slama et al., 2015). Its accumulation usually results from de novo synthesis, while increased amounts of amino acids might be due to protein degradation.

Plant antioxidant defence comprises several enzymes (catalase, peroxidase, superoxide dismutase, 
glutathione reductase), which actively remove ROS. Still, many low molecular weight components are also recognised for their antioxidant capacity, such as ascorbate, glutathione, carotenoid pigments, flavonoids (Agati \& Tattini, 2010). For example, flavonoids act in the scavenging of toxic $\mathrm{H}_{2} \mathrm{O}_{2}$ since they are oxidised by peroxidase enzymes, which use hydrogen peroxide as a substrate (MA et al., 2014). This was also evidenced from our results, where a more significant increase of flavonoids in 'Guinness' correlated with lower amounts of $\mathrm{H}_{2} \mathrm{O}_{2}$ in its leaves after dehydration compared to 'Niki'. Also, in 'Guinness', higher amounts of DPPH and a more significant increase in FRAP was observed in response to PEG treatment, which provided higher antioxidant power and free radical scavenging activity.

\section{CONCLUSIONS}

Although PEG treatment induced similar reactions in the two wheat genotypes, 'Guinness' demonstrated better water retention ability, lower membrane injury, more significant proline accumulation and higher antioxidant and free radical scavenging activity than Niki'. Thus, 'Guinness' could be regarded as more tolerant to osmotic and oxidative stresses provoked by dehydration than 'Niki', which was in accordance with its performance in the field. Additionally, the use of PEG solutions in laboratory conditions represented an excellent alternative for studying the effects of drought on young wheat plants. The chosen physiological parameters were good predictors for the dehydration reaction and could be used as express laboratory screening criteria for choosing tolerant wheat cultivars. Most eloquent differences were estimated in RWC, Injury index, osmolytes, phenolics and hydrogen peroxide contents. Disclosing the physiological features that contribute to stress tolerance would assist the selection of high-yielding varieties with better capacity to confront and survive environmental challenges.

\section{REFERENCES}

Abid M., Ali S., Qi L.K., Zahoor R., Tian Z., JiAng D., SNIDER J.L., DAI T., 2018: Physiological and biochemical changes during drought and recovery periods at tillering and jointing stages in wheat (Triticum aestivum L.) - Scientific Reports, 8: 4615. https://doi.org/10.1038/s41598-018-21441-7

Авоватта W.F., 2019: Drought adaptive mechanisms of plants - a review - Advances in Agricultural and Environmental Sciences, 2(1): 62-65. https://doi.org/10.30881/aaeoa.00022

Agati G., Tattini M., 2010: Multiple functional roles of flavonoids in photoprotection. - New Phytologist, 186: 786-793. https://doi.org/10.1111/j.1469-8137.2010.03269.x

Alexieva V., Sergiev I., MapelliS., KaranovE., 2001: The effect of drought and ultraviolet radiation on growth and stress markers in pea and wheat. Plant Cell Environment, 24(12): 1337-1344. https://doi.org/10.1046/j.1365-3040.2001.00778.x

Ashwell G., 1966: The phenol-sulphuric acid reaction for carbohydrates. - Methods in Enzymology, 8: 93-95.

Basu S., Ramegowda V., Kumar A., PereiRA A., 2016: Plant adaptation to drought stress. - F1000Research, 5: 1554. https://doi.org/10.12688/f1000research.7678.1

Bates L.S., WaldRen R.P., Teare I.D., 1973: Rapid determination of free proline for water-stress studies. - Plant and Soil, 41: 1222-1230.

BenzIE I.F., Szeto Y.T., 1999: Total antioxidant capacity of teas by ferric reducing antioxidant power assay. - Journal of Agricultural and Food Chemistry, 47: 633-636. https://doi.org/10.1021/jf9807768

Blum A., 2017: Osmotic adjustment is a prime drought stress adaptive engine in support of plant production. - Plant Cell Environment, 40: 4-10. https://doi.org/10.1111/pce.12800

Brand-Williams W., Cuvelier M.E., Berset C., 1995: Use of a free-radical method to evaluate antioxidant activity. - Food Sci Technol-Lebensm-Wiss Technol, 28(1): 25-30. https://doi.org/10.1016/S0023-6438(95)80008-5

CAKMAK I., HoRST W.J., 1991: Effect of aluminium on lipid peroxidation, superoxide dismutase, catalase, peroxidaseactivitiesinroottipsofsoybean (Glycime max L.). - Physiologia Plantarum, 83(3): 463-468. https://doi.org/10.1111/j.1399-3054.1991.tb00121.x

Chipilski R., 2015: Physiological and agronomic evaluation of drought tolerance in promising common wheat varieties. Dissertation (in Bulgarian). Institute of Plant Genetic Resources, Bulgarian Agricultural Academy. 
ElBasyoni I., Sadalla M., Baenziger S., Bockelman H., Morsy S., 2017: Cell membrane stability and association mapping for drought and heat tolerance in a worldwide wheat collection. - Sustainability, 9(9): 1606. https://doi.org/10.3390/su9091606

Gill S.S., Tuteja N., 2010: Reactive oxygen species and antioxidant machinery in abiotic stress tolerance in crop plants. - Plant Physiology and Biochemistry, 48(12): 909-930. https://doi.org/10.1016/j.plaphy.2010.08.016

He M., He C.Q., Ding N.Z., 2018: Abiotic stresses: general defenses of land plants and chances for engineering multistress tolerance. - Frontiers in Plant Science, 9: 1771. https://doi.org/10.3389/fpls.2018.01771

Ma D., Sun D., Wang C., Li Y., Guo T., 2014: Expression of flavonoid biosynthesis genes and accumulation of flavonoid in wheat leaves in response to drought stress. - Plant Physiology and Biochemistry, 80: 60-66. https://doi.org/10.1016/j.plaphy.2014.03.024

Mattos L.M., Moretti C.L., 2015: Oxidative stress in plants under drought conditions and the role of different enzymes. - Enzyme Engineering, 5: 1. https://doi.org/10.4172/2329-6674.1000136
Slama I., Abdelly C., Bouchereau A., FlowERS T., SAvoure A., 2015: Diversity, distribution and roles of osmoprotective compounds accumulated in halophytes under abiotic stress. - Annals of Botany, 115(3): 433-447. https://doi.org/10.1093/aob/mcu239

SPerdouli I., MoustaKas M., 2012: Interaction of proline, sugars, and anthocyanins during photosynthetic acclimation of Arabidopsis thaliana to drought stress.-JournalofPlantPhysiology, 169(6): 577-585. https://doi.org/10.1016/j.jplph.2011.12.015

Swain T., Goldstein J.L., 1964: The quantitative analysis of phenolic compounds. - In: PRIDHAM J.B. (ed.), Methods in polyphenol chemistry: 131-146. - London.

TuRnER N.C., 1981: Techniques and experimental approaches for the measurement of plant water stress. - Plant and Soil, 58: 339-366. https://doi.org/10.1007/BF02180062

Yemm E.W., Cocking E.C., 1955: The determination of amino acids with ninhydrin. - Analyst, 80: 209-213.

Zhishen J., Mengcheng T., Jianming W., 1999: The determination of flavonoid contents in mulberry and their scavenging effects on superoxide radicals. - Food Chemistry, 64(4): 555-559. https://doi.org/10.1016/S0308-8146(98)00102-2

\section{DVIEJU GENOTIPU KVIEČIU FIZIOLOGINĖS REAKCIJOS İ OSMOSINI STRESA PALYGINIMAS}

\section{Elisaveta Kirova, Irina Moskova, Tania Kartseva, Konstantina Kocheva}

\section{Santrauka}

Augalų atsparumo stresui mechanizmų tyrimai gali padèti atrinkti augalų veisles, turinčias didesni gebejjimą išgyventi nepalankiomis aplinkos sąlygomis. Dèl to labai svarbu nustatyti augalų fiziologines savybes, kurios didina jų atsparumą stresui. Dviejų paprastojo kviečio (Triticum aestivum L.) veislių, kurios turi skirtingų savybių ir skirtingai atsparios sausrai, augalai 48 val. buvo veikiami 20 proc. polietilenglikolio 8000 tirpalu. Jis augalams sukèlè papildomą osmosinị ir oksidacinị stresą bei skirtingas fiziologines reakcijas. Tyrimais nustatyta, kad geresniu gebejjimu lapuose sulaikyti vandenị ir ma- žesniu membranų pažeidimo laipsniu pasižymėjo 'Guinness' negu 'Niki' veislès kviečiai. Geresnis augalų gebejjimas lapuose sulaikyti vandenị ir didesnis membranų atsparumas pažeidimams teigiamai koreliavo su geresniu osmosiniu prisitaikymu, didesniu sukaupto prolino kiekiu ir didesniu antioksidaciniu gebejjimu sugerti vandenị. Palyginti su tirpiaisiais cukrais ir bendromis laisvosiomis aminorūgštimis, prolinas labiau prisidejjo prie lapų gebos išsaugoti vandenị. Manoma, kad tokị savybių derinị lèmé šios veislès genotipinis pranašumas, nuo kurio gali priklausyti geresnis produktyvumas sausros sąlygomis. 